\title{
QUO VADIS NEGARA KESEJAHTERAAN: MENEGUHKAN IDEOLOGI WELFARE STATE NEGARA HUKUM KESEJAHTERAAN INDONESIA
}

\author{
Elviandri*, Khuzdaifah Dimyatii*, dan Absori ${ }^{* * *}$ \\ Fakultas Hukum, Universitas Muhammadiyah Riau \\ Jalan Tuanku Tambusai Ujung, Pekanbaru, Riau 28291 \\ Fakultas Hukum Universitas Muhammadiyah Surakarta \\ Jalan A. Yani Tromol Pos 1, Pabelan Kartasura, Sukoharjo, Jawa Tengah 57162
}

\begin{abstract}
The constitution mandates the state to realize prosperity as stated in the 14th article of the 1945 Constitution, however empirically it seems to have no power for creating a prosperous society. The main goal of this article is to discuss perspectives and efforts for affirming the welfare state ideology. A conception of welfare law state of Indonesia requires that every state action or government must be based on a law, security and public order, makes the welfare state ideology as the foundation of government and its function (bestuursfunctie) in holding duties and responsibilities for the people welfare and creating social justice as the spirit of economic development.
\end{abstract}

Keywords: welfare state, ideology, constitution.

\section{Intisari}

Konstitusi mengamanatkan negara mewujudkan kesejahteraan yang termaktub dalam 14 pasal Konstitusi 1945, namun dalam realitas empirisnya seakan tidak memiliki kekuatan membentuk masyarakat yang sejahtera. Artikel ini bertujuan untuk memberikan pandangan dan upaya peneguhan ideologi welfare state. Konsepsi negara hukum kesejahteraan Indonesia menghendaki setiap tindakan negara atau pemerintah harus berdasarkan hukum, menjamin keamanan dan ketertiban masyarakat, menjadikan ideologi welfare state sebagai landasan kedudukan dan fungsi pemerintah (bestuursfunctie) dalam mengemban tugas, dan tanggung jawab yang lebih luas untuk mensejahterakan rakyat serta menjadikan keadilan sosial sebagai rohnya pembangunan ekonomi.

Kata Kunci: negara kesejahteraan, ideologi, konstitusi.

\section{Pokok Muatan}

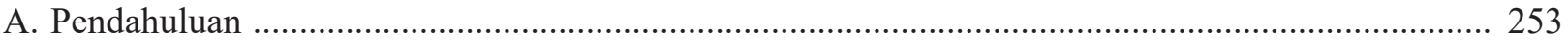

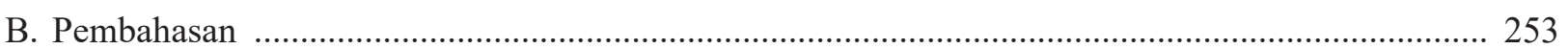

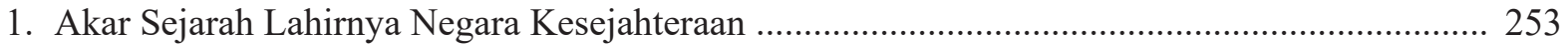

2. Perdebatan Negara Kesejahteraan: Diskursus yang Belum Usai .............................................. 253

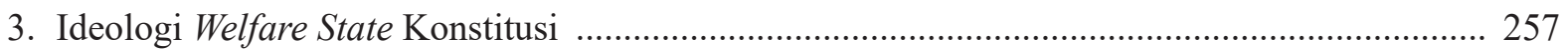

4. Negara Hukum Kesejahteraan Indonesia ............................................................................... 259

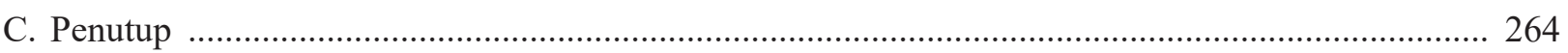

Alamat korespondensi: elviandri@umri.ac.id.

* Alamat korespondensi: kd255@ums.ac.id.

*** Alamat korespondensi: abs154@ums.ac.id 


\section{A. Pendahuluan}

Negara kesejahteraan (welfare state) dianggap sebagai jawaban yang paling tepat atas bentuk keterlibatan negara dalam memajukan kesejahteraan rakyat. Keyakinan ini diperkuat oleh munculnya kenyataan empiris mengenai kegagalan pasar (market failure) dan kegagalan negara (government failure) dalam meningkatkan kesejahteraan rakyat. ${ }^{1}$

Tujuan pendirian Negara Republik Indonesia pada dasarnya untuk mensejahterakan seluruh rakyat tanpa kecuali. Dengan kata lain negara Indonesia bertujuan untuk membentuk negara kesejahteraan. Tujuan pembangunan nasional adalah peningkatan kesejahteraan sosial bukan hanya pertumbuhan ekonomi semata tetapi untuk memenuhi berbagai kebutuhan dasar sosial dan ekonomi dari setiap warga negara agar mencapai suatu standar hidup yang minimal.

Pasal-pasal tentang kesejahteraan dalam Undang-Undang Dasar Negara Republik Indonesia Tahun 1945 (selanjutnya disebut UUD NRI 1945) dan amandemennya lebih banyak, jika dibandingkan dengan konstitusi negara lain yang bertujuan kesejahteraan seperti Norwegia, Jepang, Amerika, dan Malaysia yang memiliki indeks pembangunan manusia relatif tinggi. Indonesia memiliki 14 pasal kesejahteraan dalam UUD 1945 namun tidak memiliki kekuatan untuk membentuk masyarakat yang sejahtera jika dibandingkan dengan konstitusi negara lain yang bertujuan kesejahteraan seperti Norwegia, Jepang, Amerika, dan Malaysia yang memiliki indeks pembangunan manusianya relatif tinggi. Norwegia hanya mencantumkan 3 pasal dalam konstitusinya Pasal 110, 110a dan Pasal $110 b^{2}$ tapi mampu mencapai IPM yang hampir sempurna. Begitu juga dengan Jepang yang hanya mencantumkan 1 pasal saja tentang kesejahteraan dalam konstitusi negara Jepang. ${ }^{3}$

Rakyat mempunyai legitimasi untuk menuntut negara untuk melaksanakan apa yang menjadi kewajibannya. Maka seharusnya rakyat dapat menuntut apa yang menjadi haknya yang telah diatur begitu jelas dan tegas oleh konstitusi. Inilah yang mendorong penulis untuk merekonstruksi hukum keindonesiaan dengan meneguhkan ideologi welfare state negara hukum kesejahteraan indonesia sehingga negara benar-benar dapat bertanggung jawab untuk mewujudkan kesejahteraan. Tulisan ini akan menjawab pertanyaaan bagaimana tanggungjawab negara dalam mewujudkan welfare state, untuk menjawab pertanyaan tersebut tulisan ini mendasarkan kajiannya pada analisis konstitusional.

\section{B. Pembahasan}

\section{Akar Sejarah Lahirnya Negara Kesejah- teraan}

Menurut kamus online Merriam-Webster Dictionary, kata 'welfare' diartikan sebagai 'the state of being happy, healthy, or successful'. Dalam terjemahan bebas, kata 'welfare' mengandung beberapa makna, yakni keadaan bahagia, sehat, atau sukses. Dalam salah satu studinya, Andersen mengungkapkan bahwa welfare state:

"A welfare state is a state in which organized power is deliberately used (through politics and administration) in an effort to modify the play of the market forces in at least three directions - first, by guaranteeing individuals and families a minimum income irrespective of the market value of their work or their property; - second, by narrowing the extent of insecurity by enabling individuals and families to meet certain "social contingencies" (for example, sickness, old age and unemployment) which lead otherwise to individual and family crisis; and - third, by ensuring that all citizens without distinction of status or class are offered the best standards available in relation to a certain agreed range of social services." 4

\footnotetext{
William R. Keech, "Market Failure and Government Failure”, Paper submitted for presentation to Public Choice World Congress, Public Version 1.0-2-27-12, Miami, 2012, hlm. 5.

http://publicofficialsfinancialdisclosure.worldbank.org/sites/fdl/files/assets/law-libraryfiles/Norway_Constitution_1814_(as\%20amended)_ en.pdf, diakses 27 Maret 2017.

The Constitution Of Japan, http://japan.kantei.go.jp/constitution_and_government_of_japan/constitution_e.html, diakses 27 Maret 2017.

J. G. Andersen, 2007, Welfare States and Welfare State Theory, Aalborg: Centre for Comparative Welfare Studies, Institut for Økonomi, Politik og Forvaltning, (CCWS Working Paper), Aalborg Universitet, Denmark, hlm. 4.
} 
Welfare state merupakan institusi negara dimana kekuasaan yang dimilikinya (dalam hal kebijakan ekonomi dan politik) ditujukan untuk memastikan setiap warga negara beserta keluarganya memperoleh pendapatan minimum sesuai dengan standar kelayakan. Memberikan layanan sosial bagi setiap permasalahan yang dialami warga negara (baik dikarenakan sakit, tua, atau menganggur), serta kondisi lain semisal krisis ekonomi. Memastikan setiap warga negara mendapatkan hak-haknya tanpa memandang perbedaan status, kelas ekonomi, dan perbedaan lain.

Penelitian lain yang dilakukan Assar Lindbeck tentang Research Institute of Industrial Economics, menyatakan:

Welfare state. According to a narrow definition, the welfare state comprises two types of government spending arrangements: (i) cash benefits to households (transfers, including mandatory income insurance) and (ii) subsidies or direct government provision of human services (such as child care, preschooling, education, health care, and oldage care). By broader definitions, the welfare state may also include price regulation (such as rent control and agricultural price support), housing policies, regulation of the work environment, job-security legislation, and environmen-tal policies. This essay is confined to the narrow definition. ${ }^{5}$

Welfare state bisa dilihat dari sudut pandang terbatas dan sudut pandang luas. Dari perspektif terbatas, welfare state merupakan tata kelola keuangan pemerintah yang ditujukan untuk sektor rumah tangga (konsumsi dalam negeri, penghasilan, asuransi), serta subsidi atau dana sosial untuk kesehatan anak, pendidikan, kesehatan umum, dan perawatan orang tua. Dari sudut pandang yang luas, welfare state bisa digambarkan sebagai intervensi pemerintah melalui kebijakan publik, termasuk diantaranya kebijakan perumahan, peraturan tenaga kerja, undang-undang perpajakan, serta kebijakan lingkungan, dengan tujuan untuk kesejahteraan masyarakat.

Konsep kesejahteraan (welfare) sering diartikan berbeda oleh orang dan negara yang berbeda. Merujuk pada Spicker, Midgley, Tracy dan Livermore, Thompson, dan Suharto, pengertian kesejahteraan sedikitnya mengandung empat makna; Pertama, sebagai kondisi sejahtera (wellbeing). Pengertian ini biasanya merujuk pada istilah kesejahteraan sosial (social welfare) sebagai kondisi terpenuhinya kebutuhan material dan nonmaterial. Midgley, mendefinisikan kesejahteraan sosial sebagai “.... condition or state of human well-being". ${ }^{6}$ Kedua, sebagai pelayanan sosial, di Inggris, Australia, dan Selandia Baru, pelayanan sosial umumnya mencakup lima bentuk, yakni jaminan sosial (social security), pelayanan kesehatan, pendidikan, perumahan dan pelayanan sosial personal (personal social services). Ketiga, sebagai tunjangan sosial yang, khususnya di Amerika Serikat (AS), diberikan kepada orang miskin. Karena sebagian besar penerima welfare adalah orang-orang miskin, cacat, pengangguran, keadaan ini kemudian menimbulkan konotasi negatif pada istilah kesejahteraan, seperti kemiskinan, kemalasan, ketergantungan, yang sebenarnya lebih tepat disebut "social illfare" ketimbang "social welfare". ' Keempat, sebagai proses atau usaha terencana yang dilakukan oleh perorangan, lembaga-lembaga sosial, masyarakat maupun badan-badan pemerintah untuk meningkatkan kualitas kehidupan (pengertian pertama) melalui pemberian pelayanan sosial (pengertian kedua) dan tunjangan sosial (pengertian ketiga). ${ }^{8}$

Negara kesejahteraan sangat erat kaitannya dengan kebijakan sosial (social policy) yang di

Assar Lindbeck, 2006, The Welfare State-Background, Achievements, Problems, Research Institute of Industrial Economics, IFN Working Paper No. 662, Research Institute of Industrial Economics, Stockholm, Sweden, hlm. 2.

James Midgley, et. al., "The Handbook of Social Policy", dalam Michelle Livermore, 2000, Sage, London, hlm. xi-xv.

Edi Suharto, "Negara Kesejahteraan dan Reinventing Depsos", Seminar, Seminar "Mengkaji Ulang Relevansi Welfare State dan Terobosan melalui Desentralisasi-Otonomi di Indonesia", Institute for Research and Empowerment (IRE) Yogyakarta dan Perkumpulan Prakarsa Jakarta, Wisma MM UGM, Yogyakarta, 2006, hlm. 4.

8 Edi Suharto, Peta dan Dinamika Welfare State di Beberapa Negara: Pelajaran apa yangbisa dipetik untuk membangun Indonesia?, Makalah disampaikan pada Seminar "Mengkaji Ulang Relevansi Welfare State dan Terobosan melalui Desentralisasi Otonomi di Indonesia", Institute for Research and Empowerment (IRE) Yogyakarta dan Perkumpulan Prakarsa Jakarta, Wisma MM Universitas Gadjah Mada, Yogyakarta, 2006. 
banyak negara mencakup strategi dan upaya-upaya pemerintah dalam meningkatkan kesejahteraan warganya, terutama melalui perlindungan sosial (social protection) yang mencakup jaminan sosial (baik berbentuk bantuan sosial dan asuransi sosial), maupun jaring pengaman sosial (social safety nets).

International Tiscali Encyclopaedia menjelaskan welfare state pertama kali dipopulerkan oleh Alfred Zimern tahun 1930-an untuk membedakan antara kebijakan demokratis dengan welfare state dibeberapa kawasan Eropa yang diktator. Bagian-bagian welfare state dibangun di Jerman (1883), New Zeland (1898), AustriaHungaria (akhir abad 19), Norwegia (1909), Swedia (1910), Italia dan Rusia (1911), serta Amerika Serikat (1935). ${ }^{9}$

Welfare state diperkenalkan pada abad 18 melalui gagasan Jeremy Bentham (1748-1832), bahwa pemerintah memiliki tanggung jawab untuk menjamin kepada rakyatnya tentang kebahagiaan yang sebesar-besarnya (The greatest happines/ welfare, of the greatest number of their citizen).

Jeremy Bentham dalam konsepnya sering menggunakan istilah "utility" (kegunaan) untuk menjelaskan konsep kebahagiaan atau kesejahteraan, berdasarkan prinsip utilitarianisme yang dikembangkan Jeremy Bentham bahwa suatu yang dapat menimbulkan kebahagiaan ekstra (seluasluasnya) adalah sesuatu yang baik, namun sebaliknya bahwa sesuatu yang menimbulkan sakit adalah sesuatu yang not good (buruk), oleh karena itu pemerintah harus melakukan aksi (kebijakan dan program) yang selalu diarahkan untuk meningkatkan kebahagiaan kepada rakyat sebanyak mungkin, gagasan Jeremy Bentham untuk mewujudkan welfare state berkaitan langsung dengan reformasi hukum, peranan konstitusi dan pengembangan kebijakan sosial. Melalui pemikian Jeremy Bentham tersebut ia dikenal sebagai "Bapak Kesejahteraan Negara" (The
Father of welfare state. ${ }^{10}$

Sir William Beveridge dan T.H. Marshall yang berasal dari Inggris dalam laporannya/ pemikirannya mengenai Social Insurance and allied Sevices yang terkenal dengan nama Beveridge Report, bahwa Sir William Beveridge menyebutkan dengan istilah Want, Squalor, Ignorance, Disease, dan Idleness sebagai "The Five Giants Evils" yang harus diperangi dalam laporannya itu, Sir William Beveridge mengusulkan sebuah sistem asuransi komprehensif yang dipandangnya mampu melindungi orang dari buaian hingga liang lahat (from cradle to grave), pengaruh laporan Sir William Beveridge tidak hanya di Inggris, melainkan juga menyebar ke negara-negara lain seperti Eropa bahkan hingga ke AS dan kemudian menjadi dasar bagi pengembangan skema jaminan sosial di negara-negara tersebut. ${ }^{11}$

\section{Perdebatan Negara Kesejahteraan: Dis- kursus yang Belum Usai}

Perdebatan tentang welfare state bisa kita lihat pada pendapat Claus Offe (Some Contradicition of Welfare State), salah seorang sosiolog terkemuka dari Jeman, menuturkan bahwa kritik terhadap welfare state, dari kubu konservatif, pada dasarnya dapat diringkas menjadi dua: ${ }^{12}$ Pertama sistem kesejahteraan dipandang mengganggu perkembangan modal dan investasi (disincentive to investment) karena pajak yang tinggi dan regulasi yang ketat dikarenakan pada pelaku usaha dianggap membuat disinsentif karena tingkat laba yang diperoleh menjadi kecil dan tidak menarik; Kedua sistem kesejahteraan, hak-hak sosial ekonomi dan peran kuat dari asosiasi serikat pekerja dipandang mengurangi insentif untuk kerja lebih keras (disincentive to work), ketimbang apabila mereka bekerja di bawah lingkungan sistem pasar bebas.

$\mathrm{Offe}^{13}$ di sisi lain menjelaskan bahwa welfare

\footnotetext{
International Tiscali Encyclopaedia (on-line), "welfare state”, http://www.tiscali.co.uk/reference/welfarestate, diakses 27 Juni 2016. Edi Suharto, Peta dan Dinamika Welfare State di Beberapa Negara, Op.cit, hlm. 4.

Naya Amin Zaini, "Politik Hukum dan HAM (Kajian Hukum Terhadap Kewajiban Pemenuhan dan Perlindungan Hak Asasi Manusia dalam Konstitusi Indonesia)", Jurnal Panorama Hukum, Vol.1, No.2, 2016, hlm. 5-6.

12 Claus Offe, "Some Contradiction of the Modern Welfare State", dalam Christoper Pierson dan Fracis G. Castels, 2000, The Welfare State Reader, Polity Press, Cambridge, hlm. 67-76.

13 Ibid.
} 
state juga dihujani kritik-kritik yang tajam dari kubu sosialis. Offe meringkas bahwa kritik kubu sosialis ada tiga: Pertama welfare state dipandang sebagai sistem dan kelembagaan yang tidak efisien dan tidak efektif atau dianggap sebagai terlalu sedikit dan terlalu terlambat dalam menata dan memperbaiki ketimpangan sosial ekonomi yang ada; Kedua represif, dalam arti bahwa para warga negara penerima manfaat (berbagai tunjangan) sering kali wajib mengikuti syarat-syarat, dan prosedur untuk memperoleh tunjangan-tunjangan dan karena itu harus berhadapan dengan sistem birokrasi; dan Ketiga menciptakan pemahaman yang keliru tentang kenyataan sosial dan politik dari kelas pekerja. ${ }^{14}$ Bahwa seakan-akan ada dua dunia; dunia kerja dan dunia hak. Padahal, keduanya tak terpisahkan dan bahwa produksi (pertumbuhan ekonomi) sendiri dapat diubah oleh mereka. Ringkasnya, welfare state hanya sekedar sarana untuk menstabilkan sistem ekonomi kapitalis ketimbang sebagai sarana untuk perubahan mendasar dalam masyarakat kapitalis.

Lebih jauh, welfare state juga dicerca oleh kalangan feminis dan kubu lingkungan hidup. Kaum feminis, seperti Carole Pateman menyatakan bahwa sistem welfare state masih bertumpu pada sistem sosial laki-laki/patriarki, dimana laki-laki dianggap sebagai pencari nafkah (male breadwinner) dan kerja-kerja kaum perempuan (kerja domestik, pengasuhan dan perawatan anak) tidak dihargai penting dalam ekonomi dan welfare state, barang kali dengan pengecualian Swedia. Sementara itu, dari kubu kaum ekologis, mereka mengkritik bahwa welfare state masih bertumpu pada asas produktivis ekonomi, yakni mengandalkan produksi dan pertumbuhan ekonomi (GNP,GDP) yang tiada batasnya, yang akhirnya akan merusak lingkungan juga. ${ }^{15}$
Istilah social security di Amerika Serikat mengacu pada program the Federal Old Age, Survivors and Disability Insurance (OASDI). Program ini menyediakan manfaat untuk pensiun, cacat, keselamatan dan kematian dari dunia kerja tapi tidak mencakup asuransi tuna karya (unemployment insurance) atau manfaat- manfaat bantuan sosial (social assistance) lainnya yang menggunakan penghasilan sebagai dasar penentuan layak/tidak layak menerima bantuan (mean-tested). Bersama dengan program yang menyediakan bantuan berupa barang (means- tested assistance in kind) seperti food stamps, dan pelayanan untuk orang miskin (means-tested services for the poor) seperti Medicaid dan perumahan untuk umum, program-program bantuan sosial ini dikategorikan sebagai welfare atau social welfare. ${ }^{16}$

Perdebatan tentang konsep welfare state yang banyak mengundang kontroversi, dan terjadi debat yang terus-menerus sebenarnya tidak lepas dari mengenai seberapa jauh tanggungjawab pemerintah terhadap kesejahteraan dan dapat kita kerucutkan masing-maisng argumentasinya pade tabel sebagai berikut: ${ }^{17}$

Tabel. 1.1

\section{Argumetasi Pro dan Kontra Konsep Welfare} State

\begin{tabular}{|c|c|}
\hline $\begin{array}{l}\text { Argumetasi Pro } \\
\text { (Mendukung) }\end{array}$ & $\begin{array}{l}\text { Argumentasi Kontra } \\
\text { (Menolak) }\end{array}$ \\
\hline Humanitarian & Libertarian \\
\hline Democratic & Conservative \\
\hline Social & Individualist \\
\hline Economic & Economic \\
\hline Mutual self-interest & Anti-regulatory \\
\hline Religious & \multirow[t]{3}{*}{ The free market } \\
\hline Ethical-reciprocity & \\
\hline $\begin{array}{l}\text { The failure of the private } \\
\text { sector }\end{array}$ & \\
\hline
\end{tabular}

Sumber: Diolah oleh Penulis, 2019.

14 Ibid.

15 Sugeng Bahagijo dan Darmawan Triwibowo, "Memahami Negara Kesejahteraan: Beberapa Catatan Bagi Indonesia”, Jurnal Politika, Vol.2, No.3, 2006, hlm. 17-18.

16 Alfitri, "Ideologi Welfare State dalam Dasar Negara Indonesia: Analisis Putusan Mahkamah Konstitusi Terkait Sistem Jaminan Sosial Nasional", Jurnal Konstitusi, Vol.9, No.3, 2012, hlm. 454-456.

17 Howard J Wiarda, 2001, European Politics in the Age of Globalization, Harcourt College Publisher, Philadelphia. Lihat juga Sophiana Widiastutie, "Profil Negara Eropa Negara-negara Nordic (The Nordic Countries)", Jurnal Kajian Wilayah Eropa, Vol. II, No. 3, 2006, hlm. $167-168$

18 Ibid. 
Argumetasi Pro atau yang mendukung penuh Konsep WelfareState dapatdipahami sebagai berikut, mereka mendasarkan pada: 1) humanitarian adalah gagasan agar rakyat tidak menderita); 2) democratic, pemilih di sebagian besar negara-negara Nordic menginginkan perluasan jaminan sosial secara bertahap; 3) ethical-reciprocity merupakan prinsip moral yang universal, dan sebagian besar sistem kesejahteraan berdasarkan pola "saling". Altruisme atau menolong sesama adalah kewajiban moral di hampir semua budaya, dan bantuan serta dukungan untuk orang yang miskin adalah merupakan prinsip moral yang universal; 4) religious yaitu, sebagian besar agama dunia menekankan akan pentingnya organisasi sosial dibandingkan dengan kepentingan diri pribadi semata. Kewajiban religius termasuk diantaranya memiliki rasa solidaritas kepada sesama; 5) mutual self-interest adanya beberapa sistem nasional medorong pertumbuhan mutual insurance); 6) economic, merupakan program sosial yang ditujukan untuk berbagai macam fungsi ekonomi, seperti misalnya: regulasi terhadap permintaan dan struktur pasar tenaga kerja); 7) social, yaitu, program sosial yang ditujukan untuk bidang pendidikan, keluarga dan pekerjaan; 8) the failure of the private sector, memberikan advokasi mengenai ketentuan-ketentuan sosial yang diwajibkan pada sektor privat yang bertentangan dengan tujuan sosial. ${ }^{18}$

Adapun argumentasi kontra atau yang menolak konsep welfare state mendasarkan konsep mereka pada: 1) libertarian (intervensi negara melanggar kebebasan individu; individu tidak seharusnya tergantung pada subsidi pihak lain untuk kepentingannya; 2) conservative (pengeluaran sosial memberikan efek yang kurang baik bagi perilaku, memupuk ketergantungan, dan menurunkan semangat kerja; 3) economic (pengeluaran sosial membutuhkan biaya besar dan pajak yang tinggi. Welfare state memberikan efek yang kurang baik bagi ekonomi sehingga secara paradoks memberikan efek negatif pada kesejahteraan rakyat; 4) individualist (pengeluaran sosial mengurangi kebebasan menikmati kemakmuran dan kesuksesan individual dengan mernbagikan sebagian dari kemakmurannya kepada orang lain argumen ini juga penting bagi kaum libertarian dan konservatif); 5) anti-regulatory (welfare state adalah pembenaran dari kontrol negara yang lebih besar kepada bisnis, membatasi pertumbuhan dan menciptakan pengangguran; 6) the free market advokasi kepada pasar akan mendorong produksi yang lebih efektif dan efisien dibandingkan dengan menyelenggarakan program-program sosial. ${ }^{19}$

\section{Ideologi Welfare State Konstitusi}

Teori negara hukum mengharuskan lembagalembaga pemegang kekuasaan negara menjalankan kekuasaannya di bawah kendali hukum. Fungsi negara ditentukan oleh tipe-tipe negara yang dianut. Umumnya negara yang berideologi hukum formal (klasik) mengenal tipe negara liberal individualis kapitalistik, sehingga dalam perwujudannya, negara yang bertipe semacam ini semata-mata bertindak sebagai penjaga malam (nachtwachter-staat, Nachwachter). ${ }^{20}$

Tugas pokok negara yang menganut ideologi semacam ini, dititik beratkan pada bagaimana menjamin dan melindungi status ekonomis dari kelompok yang menguasai alat-alat pemerintahan yang dalam sistem klas dikenal dengan istilah rulling elite, yang merupakan klas penguasa atau golongan eksekutif. Paham negara hukum formal seperti ini menimbulkan berbagai akibat buruk bagi kalangan selain the rulling class atau klas bawah dalam wujud: (1) kelas bawah tidak mendapat perhatian serius oleh alat-alat pemerintahan; (2) lapangan pekerjaan alat- alat pemerintahannya sangat sempit; (3) terjadi pemisahan antara negara dan masyarakatnya. ${ }^{21}$ Dengan demikian, apabila paham negara hukum formal liberalistik dipertahankan, maka rakyat kebanyakan akan mengalami penderitaan dan

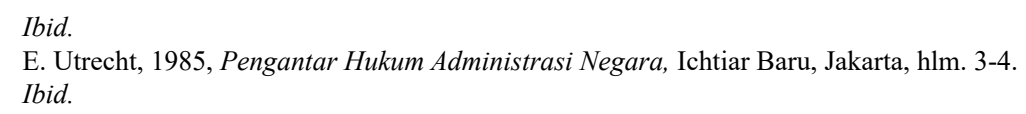


kemiskinan yang 'dalam', sementara kalangan eksklusif akan semakin kaya karena tipe negara yang memiliki paham seperti ini hanya memberi proteksi kepada kalangan elite, sehingga cita-cita negara untuk memakmurkan rakyaknya justru terbalik, dimana rakyat menjadi tidak berdaya dan hidup di bawah ambang batas (di bawah garis kemiskinan).

Pengalaman buruk yang ditunjukkan tipe negara yang berideologi hukum formal (klasik) tersebut dalam bentuk penderitaan-penderitaan sosial memberi pencerahan kepada para pemikir dan konseptor kenegaraan untuk berusaha keras mencari konsep-konsep negara yang dianggapnya lebih sesuai dengan nilai-nilai dasar yang dikehendaki rakyatnya. Dari pencarian tersebut melahirkan 2 (dua) ideologi, yakni sebagai berikut:

Pertama, aliran pemikiran yang memandang bahwa upaya untuk menghilangkan keburukankeburukan sosial yang ditimbulkan oleh sistem negara yang berideologi liberal kapitalistik hanya dengan jalan sosialisasi masyarakat sepenuhpenuhnya. Kaum sosialis ini, utamanya yang beraliran sosialis ilmiah yang dipelopori Karl Max secara radikal mendasarkan pandangangannya pada konsep sosialisasi mutlak. Baginya, keburukankeburukan sosial yang ditimbulkan konsep negara berideologi liberal individualistik berakar pada dibenarkannya hak milik perseorangan atas alatalat produksi dan bersamaan dengan itu diberikan kebebasan berusaha untuk mengejar keuntungan pribadi. ${ }^{22}$

Kedua, aliran pemikiran yang berusaha mempertahankan tingkat kebebasan sejauh mungkin dalam negara hukum sembari membenarkan perlunya negara campur tangan dalam penyelenggaraan kesejahteraan rakyat (umum) semaksimal mungkin. Ideologi dan paham negara demikian berusaha mengkombinasikan asas negara hukum dengan asas negara sosialis. Aliran pemikiran ini sampai pada konsepsi tentang socio- capitalist state yang mengutamakan fungsi welfare sebagaimana diperkenalkan oleh Mac Iver. Dalam perkembangannya, aliran ini memandang bahwa negara tidak lagi berfungsi sebagai instrument kekuasaan semata (instrument of power) melainkan mulai dipandang sebagai tool pelayanan (an agency of service). Dalam suasana alam pikiran semacam inilah timbul dan berkembang gejala "welfare state" sebagai jawaban para pemikir kenegaraan terhadap keburukan-keburukan sosial yang ditimbulkan konsep negara yang berideologi liberal individualis kapitalistik dan konsep negara yang berideologi socio-capitalist state. ${ }^{23}$

Ideologi welfare state mengajarkan tentang peranan negara yang lebih luas ketimbang sekedar sebagai penjaga malam, yang oleh Utrecht dikatakan bahwa lapangan pekerjaan pemerintah suatu negara hukum modern sangat luas, yaitu bertugas menjaga keamanan dalam arti kata yang seluas-luasnya, yakni keamanan sosial di segala bidang kemasyarakatan dalam suatu welfare state. Sehingga ketika itu, para pemikir kenegaraan menyatakan bahwa masa ekonomi liberal telah ditinggalkan, sistem ekonomi liberal klasik diganti dengan sistem ekonomi yang dipimpin oleh pusat (central geleide economie), Staatssonthouding telah digantikan oleh Staatsbemoeenis, pemisahan antara negara dengan masyarakatnya telah ditinggalkan.

Perwujudan ideologi welfare state oleh negara-negara Anglo Saxon yang versi konsep negara hukumnya dipengaruhi oleh sistem the rule of law sebagaimana diperkenalkan AV. Dicey dengan konsep rule of law yang memiliki unsur-unsur sebagaimana berikut: Pertama, supremasi aturanaturan hukum (supremacy of the law) yaitu tidak adanya kekuasaan sewenang-wenang (absence of arbitrary power) dalam arti bahwa seseorang hanya boleh dihukum apabila melanggar hukum; Kedua, kedudukan yang sama di hadapan hukum (equality before the law); Ketiga, terjaminnya hak-hak asasi manusia oleh undang-undang (oleh Undang-

\footnotetext{
22 Marilang, "Keadilan Sosial bagi Seluruh Rakyat (Studi Pengelolaan Tambang)", Jurnal Penelitian dan Pengembangan Keilmuah Secara Aktual, Edisi Khusus, Juni, 2010, hlm. 110.

23 W. Riawan Tjandra, 2008, Hukum Administrasi Negara, Universitas Atma Jaya, Yogyakarta, hlm. 23
} 
Undang Dasar di negara lain seperti antara lain Indonesia) serta keputusan-keputusan pengadilan.

Ideologi negara kesejahteraan (welfare state) menjadi landasan kedudukan dan fungsi pemerintah (bestuursfunctie) oleh negara-negara modern. Konsep negara kesejahteraan lahir atas dasar pemikiran untuk melakukan pengawasan yang ketat terhadap penyelenggaraan kekuasaan negara, khususnya eksekutif yang pada masa monarki absolut telah terbukti banyak melakukan penyalahgunaan kekuasaan. ${ }^{24}$

\section{Negara Hukum Kesejahteraan Indonesia}

Berkenaan dengan tema sentral yang akan diangkat pada penulisan ini, maka terlebih dahulu akan dijelaskan konsepsi negara hukum kesejahteraan. Menurut penulis, konsepsi negara hukum kesejahteraan merupakan landasan pemikiran dalam mengembangkan sistem ekonomi kerakyatan. Sebab, di dalam konsepsi negara hukum kesejahteraan termuat nilai-nilai keadilan yang merupakan rohnya pembangunan ekonomi.

Paham negara hukum kesejahteraan sering juga disebut sebagai negara hukum modern dalam arti material. Bagir Manan mengatakan bahwa konsep Negara hukum kesejahteraan adalah:

"Negara atau pemerintah tidak sematamata sebagai penjaga keamanan atau ketertiban masyarakat, tetapi pemikul utama tanggung jawab mewujudkan keadilan sosial, kesejahteraan umum, dan sebesarbesarnya kemakmuran rakyat". 25

Negara Hukum kesejahteraan menurut Bagir Manan terebut menempatkan negara atau pemerintah tidak saja sebagai penjaga keamanan atau ketertiban masyarakat, tetapi memiliki tanggung jawab untuk mewujudkan kesejahteraan sosial dan kesejahteraan umum bagi rakyatnya.
Bagir Manan dalam karyanya yang lain menyatakan bahwa konsepsi negara hukum modern atau negara hukum kesejahteraan mengandung tiga aspek yaitu: aspek politik, hukum, dan sosialekonomi. Aspek politik menghendaki adanya pembatasan kekuasaan negara dalam kehidupan politik. Aspek hukum mengharuskan negara adanya prinsip supremasi hukum dalam proses penegakkan hukum, asas legalitas dan rule of law, sedangkan aspek sosial menghendaki terciptanya keadilan sosial dan kesejahteraan umum.

Ciri-ciri negara hukum kesejahteraan menurut Muchsan adalah, Negara bertujuan mensejahterakan kehidupan warganya secara merata, dan negara dituntut untuk memberikan pelayanan yang sebaik-baiknya dan seluas-luasnya kepada masyarakat. Tanpa pelayanan yang baik dan merata mustahil akan terwujud kesejahteraan pada kehidupan masyarakat. Sehubungan dengan ciriciri tersebut maka ada dua gejala yang pasti muncul dalam negara kesejahteraan, yakni Pertama campur tangan pemerintah terhadap aspek kehidupan masyarakat sangat luas dan Kedua dalam pelaksanaan fungsi pemerintah sering digunakan asas diskresi. Intervensi pemerintah terhadap aspek kehidupan masyarakat ini dituntut demi terciptanya kesejahteraan masyarakat yang mera, bukan kesejahteraan menurut konsepsi liberal. Dengan adanya campur tangan ini, dapat dihindari terjadinya free fight liberalism, yang hanya akan menguntungkan pihak yang kuat saja". ${ }^{26}$

Apabila diamati, konsepsi negara hukum kesejahteraan sesungguhnya merupakan pengembangan dari konsepsi negara hukum material. Dalam upaya menciptakan kesejahteraan rakyat muncul konsepsi negara hukum kesejahteraan yang diintrodusir oleh Otto Bar sebagaimana dikutip oleh Amran Muslimin, ${ }^{27}$ bahwa:

\footnotetext{
24 Marilang, "Ideologi Welfare State Konstitusi: Hak Menguasai Negara Atas Barang Tambang”, Jurnal Konstitusi, Vol. 9, No. 2, Juni, 2012, hlm. 264-266.

25 Bagir Manan, 1996, Politik Perundangundangan dalam Rangka Mengantisipasi Liberalisme Perekonomian, FH UNLA, Bandar Lampung, hlm. 9.

26 Muchsan, 1992, Sistem Pengawasan Terhadap perbuatan Pemerintah dan Peradilan Tata Usaha Negara di Indonesia, Liberty, Yogyakarta, hlm. 4-5

27 Amran Muslimin, 1982, Beberapa Asasasas dan Pengertianpengertian Pokok Tentang Administrasi Dan Hukum Administrasi, Alumni, Bandung, hlm. 87.
} 
Negara hukum modern menjadi Negara yang bersifat Negara Kebudayaan (culturstaaf) atau Negara Kesejahteraan (welvaarstaat). Negara dianggap sebagai perusahaan yang medatangkan manfaat bagi rakyat, karena menyelenggarakan kepentingan umum dan melalui (wetmatigheid van udministratie). Saluran-saluran hukum dibuat oleh Raja bersama-sama dengan rakyat. Jadi rakyat ikut menentukan kepentingan umum, bukan raja sendiri seperti dalam polizeistaat.

Menurut Mac Iver, negara tidak dipandang lagi sebagai alat kekuasaan (instrument of power) semata, tetapi lebih dari itu, dipandang sebagai alat pelayanan (an agency of services). Paham yang pragmatis ini, kemudian melahirkan konsepsi negara kesejahteraan (welfare state) atau negara hukum modern atau negara hukum material, yang menurutnya memiliki ciri-ciri sebagai berikut: ${ }^{28}$ 1) Dalam negara hukum kesejahteraan, yang diutamakan adalah terjaminnya hak-hak asasi sosial ekonomi rakyat; 2) Pertimbanganpertimbangan efisiensi dan manajemen lebih diutama-kan daripada pembagian kekuasaan yang berorientasi politis, sehingga peran eksekutif lebih besar daripada peran legislatif; 3) Hak milik tidak bersifat mutlak; 4) Negara tidak hanya menjaga ketertiban dan keamanan, tetapi juga turut serta dalam usaha-usaha sosial dan ekonomi; 5) Kaidahkaidah hukum administrasi semakin banyak mengatur sosial ekonomi dan membebankan kewajiban tertentu kepada warga negara; 6) Peran hukum publik condong mendesak hukum privat, sebagai konsekuensi semakin luasnya peran negara; 7) Lebih bersifat negara hukum material yang mengutamakan keadilan sosial yang material pula.

Tampak dari uraian di atas, bahwa peran negara telah ditempatkan pada posisi yang kuat dan lebih besar dalam menciptakan kesejahteraan umum (public welfare) dan keadilan sosial (social justice). Konsepsi negara demikian, dalam berbagai literatur disebut dengan istilah, antara lain: social services state atau an agency of services (negara sebagai alat pelayanan) atau social reehtsstaat (negara hukum sosial). Lemaire menyebutnya dengan terminologi "bestuurzor" (negara menyelenggarakan kesejahteraan umum) atau "verzorgingstaat" (negara kesejahteraan). Konsepsi negara hukum modern ini, selain menghendaki setiap tindakan negara atau pemerintah harus berdasarkan hukum, juga negara diserahi peran, tugas, dan tanggung jawab yang lebih luas untuk mensejahterakan rakyat. ${ }^{29}$

Oleh karena itu, tugas negara in case pemerintah adalah merumuskan dalam setiap undang-undang agar tujuan tersebut yaitu kesejahteraan masyarakat dapat terwujud sehingga akan terlihat dan dapat dirasakan secara nyata bahwa hukum sangat berperan dalam mewujudkan kesejahteraan masyarakat. Inilah yang oleh Satjipto Raharjo bahkan lebih jauh lagi mengatakan bahwa, "Hukum hendaknya membuat bahagia". ${ }^{30}$

Cita negara hukum kesejahteraan dimana negara berperan aktif dalam mengatur perekonomian termaktub dalam pembukaan UUD NRI 1945. Banyak istilah yang digunakan dan semuanya mengarah kepada kesejahteraan masyarakat. Para 'founding fathers" negara kita menggunanakan istilah "adil dan makmur" sebagaimana tertuang dalam Alinea kedua pembukaan Undang-Undang Dasar Negara Republik Indonesia Tahun 1945. Istilah lain adalah "kesejahteraan umum" dan keadilan sosial yang tertuang dalam Alinea keempat pembukaan UUD NRI 1945. Dalam Pasal 33 UUD NRI $1945 .^{31}$

Alinea ke IV pembukaan UUD NRI 1945 yang menyatakan "untuk memajukan kesejahteraan umum mencerdaskan kehidupan bangsa, dan ikut

\footnotetext{
Mac Iver, 1950, The Modern State, Oxford University Press, London, hlm. 4.

Marojohan S. Panjaitan, "Pengembangan Sistem Ekonomi Kerakyatan dalam Perspektif Negara Hukum Kesejahteraan Berdasarkan UUD 1945", Jurnal Wawasan Hukum, Vol. 26, No. 01, 2012, hlm. 441-451.

Satjipto Raharjo, 2006, Membedah Hukum Progresif, Penerbit Buku Kompas, Jakarta, hlm. 9-11.

31 Yohanes Suhardin, "Peranan Hukum Dalam Mewujudkan Kesejahteraan Masyarakat”, Jurnal Hukum Pro Justisia, Vol. 25, No. 3, 2007, hlm. 272.
} 
melaksanakan ketertiban dunia yang berdasarkan kemerdekaan, perdamaian abadi, dan keadilan sosial". Selain itu dalam alinea keempat juga terdapat Pancasila yang didalam sila ke lima menyatakan keadilan sosial bagi seluruh rakyat Indonesia. Jika dimaknai dalam bidang ekonomi maka rakyat berhak diperlakukan adil secara ekonomi dan dapat mengakses kesejahteraan dalam hidupnya. Dalam UUD NRI 1945 konsepsi negara hukum kesejahteraan Indonesia juga diakomodir ${ }^{32}$ dalam Pasal 27 ayat (2), Pasal 31, Pasal 32, Pasal 33, dan Pasal 34. Pasal 33 UUD NRI 1945 yang menyatakan diatur secara rinci sebagai landasan konstitusional bagi ikut sertanya negara dalam perekonomian nasional. Ketentuan Pasal 33 UUD NRI 1945 menyatakan bahwa: ${ }^{33}$

1) Perekonomian disusun sebagai usaha bersama berdasar atas asas kekeluargaan;

2) Cabang-cabang produksi yang penting bagi negara dan yang menguasai hajat hidup orang banyak dikuasai oleh negara;

3) Bumi dan air dan kekayaan alam yang terkandung di dalamnya dikuasai oleh negara dan dipergunakan untuk sebesar-besarnya kemakmuran rakyat;

4) Perekonomian nasional diselenggarakan berdasar pada demokrasi atas ekonomi dengan prinsip kebersamaan, efisiensi berkeadilan, berkelanjutan, berwawasan lingkungan, kemandirian serta dengan menjaga keseimbangan, kemajuan dan kesatuan ekonomi nasional.

Pencantuman ketentuan sistem perekonomian nasional dalam konstitusi merupakan peletakan landasan konstitusional bagi kebijakan perekonomian nasional. Konstitusi merupakan acuan kebijakan bagi pemerintah dari sebuah negara hukum kesejahteraan dalam mengambil setiap kebijakan ekonomi. Konstitusi tidak boleh dilanggar dan dikalahkan demi kepentingan ekonomi. ${ }^{34}$ Sedangkan Pasal 34 menekankan, filantropi negara harus dilakukan untuk mereka yang tidak mampu bekerja karena kefakiran, kemiskinan, dan keterlantaran. Dalam UUD NRI 1945, yang telah diamandemen, hak sosial dan ekonomi warga negara yang harus dipenuhi negara semakin diperluas, menuju extensive positive rights. Menurut Jimly Ashidiqqie ketentuan tentang ekonomi dalam UUD NRI 1945 merupakan instrumen pengendalian terhadap dinamika pasar sekaligus sarana perekayasaan perkembangan ekonomi untuk mencapai cita-cita bersama yaitu terciptanya keadilan (justice), terciptanya kemakmuran bersama dan kebebasan. Konstitusi berfungsi sebagai penyeimbang antara kepentingan negara, masyarakat dan pasar. ${ }^{35}$

Konstitusi secara jelas menginginkan terwujudnya negara kesejahteraan di Indonesia, dimana negara menganugerahkan hak sosial dan ekonomi secara luas kepada setiap warga negara. Dengan demikian, di Indonesia, negara bukanlah minimal state atau necessary evil, dan bahkan bukan pula sekadar enabling state yang hanya memodifikasi pasar seraya tetap memuja individualisme. Berdasarkan konstitusi di Indonesia, negara adalah development agents yang tidak hanya mendorong equality of opportunity, namun juga secara aktif berupaya menegakkan keadilan sosial (equality of outcome). Negara secara jelas diamanatkan untuk menempatkan kepentingan masyarakat di atas kepentingan orang perorang.

Implikasinya, negara berperan penting

32 Berbagai ketentuan kesejahteraan rakyat terdapat didalam Pasal 27 ayat (2), 31, 32, 33, dan 34 Undang-Undang Dasar Negara Republik Indonesia Tahun 1945. Pasal 27 ayat (2) menentukan bahwa tiap-tiap warganegara berhak atas pekerjaan dan penghidupan yang layak bagi kemanusiaan; Pasal 31 menentukan bahwa tiap-tiap warganegara berhak mendapat pengajaran; Pasal 32 menentukan mengenai tugas pemerintah untuk memajukan kebudayaan nasional; dan Pasal 34 menentukan bahwa fakir miskin dan anak-anak terlantar dipelihara oleh negara. Sedang Pasal 33 mengatur mengenai masalah ekonomi, yang menganut sistem kekeluargaan, dan menentukan bahwa cabang-cabang produksi yang penting bagi rakyat dan bumi dan air, dan kekayaan alam yang ada diatasnya dikuasai oleh negara.

33 Undang-Undang Dasar Negara Republik Indonesia Tahun 1945.

34 Muh. Risnain, "Peningkatan Daya Saing Bangsa Melalui Reformasi Pembangunan Hukum Dalam Mewujudkan Cita Negara Kesejahteraan", Jurnal RechtsVinding, Vol. 5, No. 3, 2016, hlm. 300.

35 Jimly Assidiqqie, 2010, Konstitusi Ekonomi, Kompas Gramedia, Jakarta, hlm. 68-70. 
dalam penyediaan barang dan jasa publik (provider state) menuju unconditional welfare state, dengan kebijakan fiskal (keuangan negara) secara aktif menjalankan fungsi redistribusi pendapatan untuk keadilan sosial. Dengan melakukan tafsir ekonomi atas konstitusi, maka untuk kasus Indonesia, model welfare state berdasarkan UUD NRI 1945 akan terdiri dari empat pilar utama, yaitu: ${ }^{36}$ Pertama, sistem jaminan sosial universal, sebagai backbone program kesejahteraan; Kedua, pembangunan berbasiskan keunggulan sumber daya produktif perekonomian untuk pemenuhan hak-hak dasar warga negara, khususnya kesehatan dan pendidikan, sebagai penopang sistem jaminan sosial untuk mencapai efisiensi dan mencegah eskalasi biaya jaminan sosial, serta memfasilitasi tenaga kerja dengan keahlian yang dibutuhkan untuk masuk ke pasar tenaga kerja; penciptaan lapangan kerja secara luas sebagai titik tolak pembangunan, dan menyusun ulang perekonomian dalam rangka redistribusi aset dan alat produktif, dengan koperasi sebagai bentuk badan usaha yang paling dominan dalam perekonomian;

Ketiga, pertumbuhan ekonomi yang tinggi, inklusif, berkeadilan, dan berorientasi pada pemerataan (redistribution with growth), sebagai hasil redistribusi aset dan alat produksi, serta penguasaan produksi secara bersama-sama melalui koperasi, dengan sektor-sektor strategis yang menguasai hajat hidup orang banyak dikuasai oleh negara. Keempat, reformasi birokrasi dan penguatan kapasitas fiskal, untuk penciptaan pemerintahan yang kuat dan responsif sebagai agent of development dan penyedia barang dan jasa publik secara luas, serta pengelolaan sumber daya alam dan sektor-sektor strategis yang menguasai hajat hidup orang banyak dan penting bagi negara, sebagai penopang welfare state untuk menegakkan keadilan sosial.

Fokus kajian pembahasan negara hukum kesejahteraan Indonesia adalah pada pilar pertama yaitu tentang Sistem jaminan sosial universal, sebagai backbone program kesejahteraan. Kebijakan pemerintah untuk menyelenggarakan sistem jaminan sosial yang berlaku universal bagi seluruh warga negara Indonesia adalah konsekuensi dari amendemen kedua UUD NRI 1945 yang disetujui pada tanggal 18 Agustus, 2000 terutama tentang Hak Asasi Manusia "Setiap orang berhak atas jaminan sosial...," vide Pasal 28H (3). Juga, amende-men keempat yang disetujui pada 10 Agustus 2002, khususnya revisi klausul kesejahteraan sosial, dimana pemerintah bertanggung jawab untuk mengembangkan sistem jaminan sosial bagi seluruh rakyat Indonesia (Pasal 34 ayat (2)). Dalam pandangan Majelis Permusyawaratan Rakyat, sebagai lembaga yang berwenang membuat dan mengubah undang-undang dasar, fungsi negara untuk mengembangkan jaminan sosial dimaksud bukan hanya dipandang masih tetap relevan melainkan justru dipertegas guna mewujudkan citacita kesejahteraan umum sebagaimana dimaksud oleh Pembukaan UUD NRI 1945 alinea keempat.

Indonesia berarti cenderung pada model institutionalist welfare state versi rezim Konservatif karena program jaminan sosial tidak sepenuhnya diserahkan kepada mekanisme pasar (swasta). Ketentuan yang menyebutkan empat perusahaan asuransi yang ada otomatis menjadi badan penyelenggara jaminan sosial telah dibatalkan oleh Mahkamah Konstitusi dalam putusan pada perkara tahun 2005 Nomor 007/PUU-III/2005 tentang Konstitutionalitas Sistem Asuransi Sosial yang Dikembangkan Undang-Undang Sistem Jaminan Sosial Nasional (UU SJSN). ${ }^{37}$ Mahkamah Konstitusi berpendapat:

“...UU SJSN telah cukup memenuhi maksud Pasal 34 ayat (2) UUD NRI 1945, dalam arti bahwa sistem jaminan sosial yang dipilih UU SJSN telah cukup menjabarkan maksud Undang-Undang Dasar yang

\footnotetext{
36 Indonesia dan Negara Kesejahteraan, http://www.republika.co.id/berita/ koran/pareto/ 16/08/15/obxy868-indonesia-dan-negarakesejahteraan, diakses 24 Maret 2017.

37 Alfitri, Op. cit., hlm. 465-468.
} 
menghendaki agar sistem jaminan sosial yang dikembangkan mencakup seluruh rakyat dan bertujuan untuk meningkatkan keberdayaan masyarakat yang lemah dan tidak mampu sesuai dengan martabat kemanusiaan...$^{38}$

Pemerintah tetap bertanggung jawab terhadap jaminan sosial seluruh warga negara dengan menyelenggarakan program jaminan sosial yang dikelola oleh sebuah badan hukum yang dibentuk pemerintah berdasarkan undang-undang. Disamping itu, prinsip subsidi yang menjadi ciri dari rezim Konservatif juga diterapkan dimana pemerintah bertanggung jawab terhadap warga negara yang miskin dan/atau tidak mampu untuk membayar iuran wajib asuransi kesejahteraan sosial (vide Pasal 10 ayat (1), ayat (2) Undang-Undang Nomor 11 Tahun 2009 tentang Kesejahteraan Sosial dan Asuransi Kesehatan (vide Pasal 17 ayat (4), Pasal 20 ayat (1), dan Pasal 21 ayat (1), ayat (2), ayat (3) Undang-Undang Nomor 40 Tahun 2004 tentang Sistem Jaminan Sosial Nasional (selanjutnya disebut UU SJSN)).

Mahkamah Konstitusi ternyata membenarkan tafsiran ideologi welfare state versi pemerintah yang cenderung kepada kebijakan institutionalist yang Konservatif dan bukan institutionalist yang Demokrasi Sosial seperti yang didalilkan oleh para pemohon. Pertimbangan Mahkamah Konstitusi bahwa pemberlakuan sistem asuransi sosial telah sesuai dengan norma welfare state dalam Pembukaan UUD NRI 1945 dan Pasal 34 UUD NRI 1945 bisa disarikan sebagai berikut: ${ }^{39}$

Pertama, paham negara kesejahteraan Indonesia adalah paham yang terbuka terhadap model welfare state yang ada; konstitusi negara Indonesia telah memberikan kriteria konstitusionalnya, yaitu Pasal 34 ayat (2) UUD NRI 1945 "komprehensif dan pemberdayaan masyarakat tidak mampu"; sepanjang sistem yang kemudian dianut oleh pemerintah telah memenuhi kriteria Konstitusional tadi, maka sistem itu sesuai dengan paham negara kesejahteraan Indonesia. Kedua, konsep jaminan sosial dalam UU SJSN yang mewajibkan orang yang memenuhi syarat untuk menjadi peserta asuransi dan kemudian untuk membayar premi program-program jaminan sosial, sedangkan pemerintah membiayai orang yang tidak mampu membayar premi, telah menerapkan prinsip asuransi sosial dan kegotong-royongan.

Pertimbangan Mahkamah Konstitusi bahwa paham negara kesejahteraan yang dianut Indonesia adalah paham yang terbuka lebih sesuai dengan fakta sejarah kebijakan kesejahteraan sosial (social welfare) di Indonesia. Para pendiri negara tidak menetapkan secara spesifik model welfare state seperti apa yang dimaksud oleh Pancasila dan UUD NRI 1945, padahal waktu paham negara kesejahteraan Indonesia dimasukkan ke dalam dasar negara tahun 1945 itu dua model welfare state (institutionalist dan residualist) beserta tiga variasinya (Demokrasi Sosial, Konservatif, dan Liberal) sudah berkembang. Dalam perjalanan kehidupan berbangsa, negara ternyata juga tidak lebih berperan besar dari civil society (keluarga dan masyarakat) dalam memajukan kesejahteraan umum. Negara terlihat baru berperan besar melalui program sosialnya (Jamkesmas, bantuan langsung tunai, subsidi, dan operasi pasar) ketika isu kesenjangan sosial semakin nyata sebagai akibat

\footnotetext{
38 Putusan Mahkamah Konstitusi Nomor 50/PUU-VIII/2010, perihal Pengujian Undang-Undang Nomor 40 Tahun 2004 tentang Sistem Jaminan Sosial Nasional terhadap UndangUndang Dasar Negara Republik Indonesia Tahun 1945, 11 November 2011, hlm. 91. Jo. Putusan Mahkamah Konstitusi Nomor 007/PUU-III/2005 perihal Konstitutionalitas Sistem Asuransi Sosial yang Dikembangkan Undang-Undang Sistem Jaminan Sosial Nasional, 31 Agustus 2005, hlm. 263. Karena Mahkamah Konstitusi mempunyai pendirian yang sama pada kedua perkara, pertimbangan hukum yang dipakai Mahkamah Konstitusi pada putusan Nomor 007/PUUIII/2005 mutatis mutandis diterapkan putusan Nomor 50/PUU-VIII/2010.

39 Putusan Mahkamah Konstitusi Nomor 50/PUU-VIII/2010, perihal Pengujian Undang-Undang Nomor 40 Tahun 2004 tentang Sistem Jaminan Sosial Nasional terhadap UndangUndang Dasar Negara Republik Indonesia Tahun 1945, 11 November 2011, hlm. 91. Jo. Putusan Mahkamah Konstitusi Nomor 007/PUU-III/2005 perihal Konstitutionalitas Sistem Asuransi Sosial yang Dikembangkan Undang-Undang Sistem Jaminan Sosial Nasional, 31 Agustus 2005, hlm. 263. Karena Mahkamah Konstitusi mempunyai pendirian yang sama pada kedua perkara, pertimbangan hukum yang dipakai Mahkamah Konstitusi pada putusan Nomor 007/PUUIII/2005 mutatis mutandis diterapkan putusan Nomor 50/PUU-VIII/2010.
} 
dari krisis ekonomi yang menyebabkan jumlah masyarakat miskin meningkat dan juga daya beli masyarakat untuk memenuhi kebutuhan pokok menurun tajam. Keseluruhan program sosial ini merupakan bagian dari kebijakan welfare state, karena welfare state tidak hanya terkait dengan pemberian jaminan sosial, tapi juga kebijakan menyangkut kesejahteraan warga negara yang ditujukan untuk memperbaiki dampak eksternal ekonomi pasar melalui alokasi program-program sosial dalam belanja publik/anggaran. ${ }^{40}$

Konsep dan model welfare state sangat cair (fluid) dalam prakteknya, dan juga sering mengalami transisi dari satu model ke model lain. Contohnya model welfare state di Inggris sejak era 1970 menjadi lebih dekat ke arah bentuk Liberal dari Konservatif, karena pemerintah membatasi diri dalam menggunakan program kesejahteraan, yakni hanya untuk mengatasi kesenjangan sosial. Dalam prakteknya juga, negara-negara yang mengadopsi institutionalist-demokrasi sosial welfare state (Swedia, Norwegia dan Denmark) ternyata adalah negara maju yang berpaham pasar. Fakta lain, Bo Rothstein menemukan alokasi anggaran negara-negara industri maju untuk belanja publik, termasuk di dalamnya program sosial, meningkat secara dramatis sejak era 1960. Padahal negaranegara industri maju ini memiliki kecendrungan beragam dalam menjalankan konsep welfare state: Demokrasi Sosial bagi negara-negara Skandinavia; Konservatif bagi rata-rata negara Eropa, dan Liberal bagi Amerika Serikat. ${ }^{41}$

\section{Penutup}

Konsepsi negara hukum kesejahteraan sesungguhnya merupakan pengembangan dari konsepsi negara hukum material menempatkan negara atau pemerintah tidak saja sebagai penjaga keamanan atau ketertiban masyarakat, tetapi memiliki tanggung jawab untuk mewujudkan kesejahteraan. Dalam upaya menciptakan kesejahteraan rakyat muncul konsepsi negara hukum kesejahteraan. Ideologi negara kesejahteraan (welfare state) menjadi landasan kedudukan dan fungsi pemerintah (bestuursfunctie). Cita negara hukum kesejahteraan termaktub dalam pembukaan UUD NRI 1945. Banyak istilah yang digunakan dan semuanya mengarah kepada kesejahteraan masyarakat. Para 'founding fathers" negara kita menggunanakan istilah "adil dan makmur" sebagaimana tertuang dalam Alinea kedua pembukaan UUD NRI 1945.

Istilah lain adalah "kesejahteraan umum" dan keadilan sosial yang tertuang dalam Alinea keempat pembukaanUUDNRI1945.DalamPasal33UUDNRI 1945 menggunakan istilah "kemakmuran rakyat", konsepsi negara hukum kesejahteraan Indonesia juga diakomodir dalam Pasal-Pasal 27 ayat (2), 31, 32, 33, dan 34 UUD NRI 1945. Secara konstitusi Indonesia menganut ideologi welfare state namun dalam realitasnya semakin jauh dari kesejahteraan. Pasal demi pasal hanya sebatas bait tulisan dan tidak diimplementasikan, disinilah tanggungjawab negara dituntut untuk mewujudkan welfare state.

\section{DAFTAR PUSTAKA}

\section{A. Buku}

Assidiqqie, Jimly, 2010, Konstitusi Ekonomi, Kompas Gramedia, Jakarta.

Iver, Mac 1950, The Modern State, Oxford University Press, London.
Manan, Bagir, 1996, Politik Perundangundangan dalam Rangka Mengantisipasi Liberalisme Perekonomian, FH UNLA, Bandar Lampung. Muchsan, 1992, Sistem Pengawasan Terhadap perbuatan Pemerintah dan Peradilan

40 Bo Rothstein, 1998, Just Institution Matter: The Moral and Political Logic of the Universal Welfare State, Cambridge University Press, Cambridge, UK, hlm. 28.

41 Meskipun jika dibandingkan tetap saja negara-negara beraliran Konservatif, menghabiskan anggaran untuk belanja publik sekitar 50 persen lebih banyak dari Amerika Serikat yang beraliran liberal; sedangkan negara-negara Skandinavia yang rata-rata beraliran Demokrasi Sosial membelanjakan anggaran dua kali lipat dari Amerika Serikat. 
Tata Usaha Negara di Indonesia, Liberty, Yogyakarta

Muslimin, Amran, 1982, Beberapa Asasasas dan Pengertianpengertian Pokok Tentang Administrasi Dan Hukum Administrasi, Alumni, Bandung

Offe,Claus, "Some Contradiction of the Modern Welfare State", dalam Christoper Pierson dan Fracis G. Castels, 2000, The Welfare State Reader, Polity Press, Cambridge.

Raharjo, Satjipto 2006, Membedah Hukum Progresif, Penerbit Buku Kompas, Jakarta. Rothstein, Bo, 1998, Just Institution Matter: The Moral and Political Logic of the Universal Welfare State, Cambridge University Press, Cambridge, UK.

Tjandra, W. Riawan, 2008, Hukum Administrasi Negara, Universitas Atma Jaya, Yogyakarta.

Utrecht, E., 1985, Pengantar Hukum Administrasi Negara, Ichtiar Baru, Jakarta.

J Wiarda, Howard, 2001, European Politics in the Age of Globalization, Harcourt College Publisher, Philadelphia.

\section{B. Artikel Jurnal}

Alfitri, "Ideologi Welfare State dalam Dasar Negara Indonesia: Analisis Putusan Mahkamah Konstitusi Terkait Sistem Jaminan Sosial Nasional", Jurnal Konstitusi, Vol.9, No.3, 2012.

Bahagijo, Sugeng dan Darmawan Triwibowo, "Memahami Negara Kesejahteraan: Beberapa Catatan Bagi Indonesia", Jurnal Politika, Vol.2, No.3, 2006.

Marilang, "Ideologi Welfare State Konstitusi: Hak Menguasai Negara Atas Barang Tambang", Jurnal Konstitusi, Vol. 9, No. 2, Juni, 2012.

Marilang, "Keadilan Sosial bagi Seluruh Rakyat (Studi Pengelolaan Tambang)", Jurnal Penelitian dan Pengembangan Keilmuah Secara Aktual, Edisi Khusus, Juni, 2010.

Panjaitan, Marojohan S., "Pengembangan Sistem Ekonomi Kerakyatan dalam Perspektif Negara Hukum Kesejahteraan Berdasarkan
UUD 1945", Jurnal Wawasan Hukum, Vol. 26, No. 01, 2012.

Risnain, Muh., "Peningkatan Daya Saing Bangsa Melalui Reformasi Pembangunan Hukum Dalam Mewujudkan Cita Negara Kesejahteraan", Jurnal RechtsVinding, Vol. 5, No. 3, 2016.

Suhardin, Yohanes "Peranan Hukum Dalam Mewujudkan Kesejahteraan Masyarakat", Jurnal Hukum Pro Justisia,Vol. 25, No. 3, 2007.

Widiastutie, Sophiana, "Profil Negara Eropa Negaranegara Nordic (The Nordic Countries)", Jurnal Kajian Wilayah Eropa, Vol. II, No. 3, 2006.

Zaini, Naya Amin, "Politik Hukum dan HAM (Kajian Hukum Terhadap Kewajiban Pemenuhan dan Perlindungan Hak Asasi Manusia dalam Konstitusi Indonesia)", Jurnal Panorama Hukum, Vol.1, No.2, 2016.

\section{Hasil Penelitian}

Andersen, J. G., 2007, Welfare States and Welfare State Theory, Aalborg: Centre for Comparative Welfare Studies, Institut for Økonomi, Politik og Forvaltning, (CCWS Working Paper), Aalborg Universitet, Denmark.

Lindbeck, Assar, 2006, The Welfare StateBackground, Achievements, Problems, Research Institute of Industrial Economics, IFN Working Paper No. 662, Research Institute of Industrial Economics, Stockholm, Sweden.

Keech,William R., 2012, Market Failure and Government Failure, Paper submitted for presentation to Public Choice World Congress, Public Version 1.0-2-27-12, Miami.

\section{Makalah/Pidato}

Suharto, Edi, "Negara Kesejahteraan dan Reinventing Depsos", Seminar, Seminar "Mengkaji Ulang Relevansi Welfare State 
dan Terobosan melalui DesentralisasiOtonomi di Indonesia", Institute for Research and Empowerment (IRE) Yogyakarta dan Perkumpulan Prakarsa Jakarta, Wisma MM UGM, Yogyakarta, 2006.

\section{E. Artikel dalam Antologi dengan Editor}

Midgley, James et. al., "The Handbook of Social Policy", dalam Michelle Livermore, 2000, Sage, London.

\section{F. Internet}

Indonesia dan Negara Kesejahteraan, http:// www.republika.co.id/berita/koran/pareto/ 16/08/15/obxy868-indonesia-dan-negarakesejahteraan, diakses 24 Maret 2017.

International Tiscali Encyclopaedia (on-line), "welfare state", http://www.tiscali.co.uk/ reference/welfarestate, diakses 27 Juni 2016. http://publicofficialsfinancialdisclosure.worldbank. org/sites/fdl/files/assets/law-libraryf iles/ Norway_Constitution_1814_(as\%20 amended)_en.pdf, diakses 27 Maret 2017.

The Constitution Of Japan, http://japan.kantei. go.jp/constitution_and_government_of japan/constitution_e.html, diakses 27 Maret 2017.

\section{G. Peraturan Perundang-undangan}

Undang-Undang Dasar Negara Republik Indonesia Tahun 1945.

Undang-Undang Nomor 11 Tahun 2009 tentang Kesejahteraan Sosial dan Asuransi Kesehatan (Lembaran Negara Republik Indonesia Tahun 2009 Nomor 12, Tambahan Lembaran Negara Republik Indonesia Nomor 4967).

Undang-Undang Nomor 40 Tahun 2004 tentang Sistem Jaminan Sosial Nasional (Lembaran Negara Republik Indonesia Tahun 2004 Nomor 150, Tambahan Lembaran Negara Republik Indonesia Nomor 4456).

\section{H. Putusan Pengadilan}

Putusan Mahkamah Konstitusi Nomor 50/PUUVIII/2010, perihal Pengujian UndangUndang Nomor 40 Tahun 2004 tentang Sistem Jaminan Sosial Nasional terhadap UndangUndang Dasar Negara Republik Indonesia Tahun 1945, 11 November 2011.

Putusan Mahkamah Konstitusi Nomor 007/PUUIII/2005 perihal Konstitutionalitas Sistem Asuransi Sosial yang Dikembangkan Undang-Undang Sistem Jaminan Sosial Nasional, 31 Agustus 2005. 